Dustin, J. P., Moore, S. \& Bigwood, E. J. (1952). Int. Congr. Biochem. II. Paris. Résumés des Communications, p. 354 .

Jonxis, J. H. P. (1951). Voeding, 12, 309.

Jonxis, J. H. P., Smith, P. A. \& Huisman, T. H. J. (1952). Lancet, 263, 1015.

Moore, S. \& Stein, W. H. (1951). F. biol. Chem. 192, 663.

Schram, E., Dustin, J. P., Moore, S. \& Bigwood, E. J. (1953a). Analyt. chim. acta, 9, 149.

Schram, E., Dustin, J. P., Moore, S. \& Bigwood, E. J. (1953b). Analyt. chim. acta, 9, 256.

\title{
Dehydroascorbic Acid in Human Blood Plasma
}

\author{
By C. P. Stewart, D. B. Horn and J. S. Robson, Clinical Laboratory, Royal \\ Infirmary, Edinburgh
}

The existence of dehydroascorbic acid in human plasma

A year ago we (Stewart, Horn \& Robson, 1952, 1953) showed that human blood plasma contains quite considerable amounts of dehydroascorbic acid. Previously it had been generally believed that this substance was not present in blood plasma or was present only in negligibly small concentration. The evidence on which we founded our statement was as follows.

In the first place, a colorimetric method of determining ascorbic acid by its power of reducing indophenol gave results consistently lower than those obtained, in the same plasma, by the method of Roe \& Kuether (1943) which measures dehydroascorbic acid and diketogulonic acid in addition to ascorbic acid. Control experiments with the two methods suggested that the difference was real, and observations on the stability of ascorbic acid in plasma negatived the idea that oxidation of ascorbic acid might be occurring in the plasma (or whole blood) after its withdrawal or during the actual determination with indophenol. Further, treatment of plasma or plasma filtrates with pure hydrogen sulphide produced an increase in the ascorbic acid measured by indophenol exactly equal to the dehydroascorbic acid calculated as being present originally. Not only did these experiments very strongly suggest the presence of dehydroascorbic acid in human plasma - in amounts varying from below 0.1 to $0.36 \mathrm{mg} / 100 \mathrm{ml}$. - but they suggested, equally strongly, the virtual absence of diketogulonic acid, since this substance is not reduced by hydrogen sulphide but reacts with dinitrophenylhydrazine under the conditions used by Roe \& Kuether.

Confirmatory evidence of a similar character was obtained during experiments in which the apparent ratio of ascorbic acid to dehydroascorbic acid was altered, but since our original publication we have sought confirmation by using a different reducing agent in place of the non-specific hydrogen sulphide. Dr Mapson kindly gave us a culture of the Bacterium coli strain which he and Ingram (Mapson \& Ingram, 195I) had shown to be capable of reducing dehydroascorbic acid quantitatively to ascorbic acid. Suspensions of this organism, shown to be fully active by control experiments with aqueous solutions freshly prepared to contain dehydroascorbic acid, were incubated with plasma under the conditions of $\mathrm{pH}$ and anaerobiosis described by Mapson \& Ingram. In each experiment the preformed ascorbic 
acid was measured by the indophenol method, the 'total' was measured by the Roe \& Kuether method, and the indophenol-reducing power was measured after treatment with hydrogen sulphide and also after incubation with the bacteria. The behaviour of the final solution after addition of indophenol showed-the colour density remaining stable over the period of observation-that it was ascorbic acid that was being measured. The results are shown in Table I*. Evidently the substance in the original plasma which reacts with dinitrophenylhydrazine but not with indophenol is reduced to an indophenol-reducing substance (resembling ascorbic acid in its rapidity of reaction with indophenol) both by hydrogen

Table I. Effect of Bact. coli on the ascorbic-acid content of plasma ( $\mathrm{mg} / 100 \mathrm{ml}$.)

Plasma

Ascorbic acid (by indophenol-titration)

Ascorbic acid after $\mathrm{H}_{2} \mathrm{~S}$ treatment

Ascorbic acid after treatment with Bact. coli.

Total ascorbic acid (method of Roe \& Kuether, r943)

$\begin{array}{ccccc}\text { I } & 2 & 3 & 4 & 5 \\ 0.25 & 0.33 & 0.6 \text { I } & 0.15 & \text { I.23 } \\ 0.40 & 0.42 & 0.68 & 0.28 & 1.35 \\ 0.42 & 0.49 & 0.69 & 0.29 & 1.37 \\ 0.44 & 0.50 & - & 0.28 & -\end{array}$

sulphide and by Bact. coli. Calculated as ascorbic acid, the increase in indophenolreducing substance produced by both agents accounts, within experimental error, for the difference between the figures given for the original plasma by the indophenol and the Roe \& Kuether methods.

Incidentally, it may be remarked, dehydroascorbic acid has been demonstrated by the same methods, in the plasma of the rabbit and of the rat.

\section{Effect of various agents on the dehydroascorbic acid content of plasma}

\section{Cortisone}

Because of the known relationship between vitamin $\mathrm{C}$ and the adrenal cortex, the effect of cortisone and of ACTH on the plasma ascorbic acid was studied. Cortisone, given orally as a suspension of the acetate, was tested in normal subjects, fasting and at rest. The dose used was $35^{\circ} \mathrm{mg}$, the plasma ascorbic acid and dehydroascorbic acid being determined before and at intervals afterwards. (Control observations over a similar period of time without cortisone administration showed virtual constancy of both). Whilst the 'total' ascorbic acid measured by the Roe \& Kuether method was unaltered, the ascorbic acid itself (indophenol method) rose so that, temporarily, the dehydroascorbic acid almost or quite disappeared from the plasma, this disappearance coinciding in time with the maximum eosinopenia. Moreover, in all these samples treatment of plasma with hydrogen sulphide (and removal of the excess by nitrogen) produced an ascorbic-acid value equal to the 'total'; when none of the substance believed to be dehydroascorbic acid was present, hydrogen sulphide did not increase the indophenol-reducing power (Table 2).

Control experiments showed that the cortisone acetate was itself unable to reduce dehydroascorbic acid in vitro, and that plasma, whether 'normal' or collected

* These experiments were made by Miss Christina Thompson. 
Table 2. Effect of cortisone on the plasma ascorbic-acid concentration ( $m g / 100 \mathrm{ml}$.). $300 \mathrm{mg}$ cortisone acetate given orally at time $\circ$

$\begin{array}{ccccc}\begin{array}{c}\text { Time } \\ \text { (h) }\end{array} & \text { Ascorbic acid } & \begin{array}{c}\text { Ascorbic acid } \\ \text { after } \mathrm{H}_{2} \text { S treatment }\end{array} & \begin{array}{c}\text { 'Total' ascorbic acid } \\ \text { (method of Roe \& Kuether, 1943) }\end{array} & \begin{array}{c}\text { Dehydroascorbic } \\ \text { acid }\end{array} \\ 0 & 0.56 & 0.75 & 0.75 & 0.19 \\ 1 & 0.76 & 0.76 & 0.75 & 0 \\ 2 & 0.62 & 0.75 & 0.75 & 0.13 \\ 3 & 0.65 & 0.75 & 0.76 & 0.21 \\ 5 & 0.56 & 0.71 & 0.75 & 0.19\end{array}$

I $\mathrm{h}$ after cortisone administration, was also without reducing power for added dehydroascorbic acid.

It is concluded that, as a result of some cellular activity, cortisone causes the rapid but temporary disappearance of dehydroascorbic acid from the plasma. Indirect evidence in support of this conclusion has recently been published by Loxton \& LeVay (1953) who found a fall in the redox potential of the peripheral tissues $\mathrm{I}-2 \mathrm{~h}$ after the oral administration of cortisone.

\section{Adrenocorticotrophic hormone}

ACTH ('Acthar', Armour \& Co. Ltd., The Armour Laboratories, London) was given intramuscularly, the dose being roo $\mathrm{mg}$ under conditions and with measurements similar to those for the cortisone experiments. The results with respect to disappearance of dehydroascorbic acid were rather like those found with cortisone (except that a little dehydroascorbic acid usually remained). There was, however, an important difference-the 'total' ascorbic acid rose significantly after ACTH whereas it did not after cortisone. Whether this represents, besides the replacement of dehydroascorbic acid by ascorbic acid, an actual withdrawal of ascorbic acid from the adrenal gland as a result of hormonal stimulation, cannot be determined by these experiments; the quantities involved, however, are such as to make such an explanation possible.

As with cortisone, the changes after ACTH were shown, by control experiments, to involve cellular intervention. Also, as before, hydrogen sulphide always reduced exactly any dehydroascorbic acid present (Table 3). These changes following administration of cortisone and ACTH, with the effects of hydrogen sulphide, constitute, in fact, an important contribution to the sum of the evidence on which rests the identification of dehydroascorbic acid in plasma.

Table 3. Effect of ACTH on the plasma ascorbic-acid concentration $(\mathrm{mg} / 100 \mathrm{ml}$.). roo $\mathrm{mg}$ ACTH given intramuscularly at time $\circ$

\begin{tabular}{|c|c|c|c|c|}
\hline $\begin{array}{l}\text { Time } \\
\text { (h) }\end{array}$ & Ascorbic acid & $\begin{array}{l}\text { Ascorbic acid } \\
\text { after } \mathrm{H}_{2} \mathrm{~S} \text { treatment }\end{array}$ & $\begin{array}{l}\text { 'Total' ascorbic acid } \\
\text { (method of Roe \& Kuether, r } 943 \text { ) }\end{array}$ & $\begin{array}{l}\text { Dehydroascorbic } \\
\text { acid }\end{array}$ \\
\hline o & 1.00 & $I \cdot 30$ & $\mathbf{I} \cdot 30$ & 0.20 \\
\hline I & 1.21 & $I \cdot 36$ & $1 \cdot 35$ & 0.14 \\
\hline 2 & $1 \cdot 15$ & $1 \cdot 36$ & $1 \cdot 35$ & 0.20 \\
\hline 3 & $1 \cdot 3^{\circ}$ & $I \cdot 45$ & $1 \cdot 50$ & 0.20 \\
\hline 4 & $I \cdot 42$ & $1 \cdot 50$ & $I \cdot 55$ & 0.13 \\
\hline 7 & 1.22 & - & $I \cdot 50$ & 0.28 \\
\hline 9 & $1 \cdot 20$ & - & $I \cdot 45$ & 0.25 \\
\hline
\end{tabular}


Sodium salicylate

Large oral doses of sodium salicylate $(7 \mathrm{~g})$ produce a rapid effect on the plasma ascorbic acid similar to that of ACTH-an increase in the 'total' ascorbic acid combined with a reduction and virtual disappearance of the dehydroascorbic acid. This was, in our experiments, associated with some degree of eosinopenia, but it was noteworthy that dehydroascorbic acid reappeared in the plasma whilst the salicylate concentration was still high. The results of one such experiment are shown in Table 4. It is tempting to think that the changes in plasma ascorbic acid indicate a stimulation of adrenal activity-either specifically by the drug or by

Table 4. Effect of $7 g$ sodium salicylate, given orally as a single dose, on the ascorbicacid concentration of the plasma

\begin{tabular}{|c|c|c|c|c|c|}
\hline \multicolumn{6}{|c|}{$(\mathrm{mg} / \mathrm{l} 00 \mathrm{ml}$. plasma $)$} \\
\hline $\begin{array}{l}\text { Time } \\
(\mathrm{h})\end{array}$ & Salicylate & Ascorbic acid & $\begin{array}{c}\text { Ascorbic acid } \\
\text { after }\end{array}$ & $\begin{array}{l}\text { 'Total' ascorbic acid } \\
\text { (method of Roe \& }\end{array}$ & Dehydroascorbic \\
\hline 0 & 0 & 0.85 & I. 10 & 1.05 & 0.20 \\
\hline 0.5 & I 7 & 0.90 & $I .06$ & 1.05 & 0.16 \\
\hline I & 28 & 0.88 & I.05 & 1.07 & 0.19 \\
\hline 2 & 29 & $I \cdot I 2$ & $\mathrm{I} \cdot \mathrm{I} 5$ & $1 \cdot 13$ & 0.01 \\
\hline 3 & 32 & $I \cdot 26$ & - & I. 24 & o \\
\hline 4 & $3 I \cdot 5$ & 1.26 & $I \cdot 30$ & 1.29 & 0.03 \\
\hline 5 & 29 & 0.85 & $1 \cdot 30$ & $I \cdot 29$ & 0.45 \\
\hline 6 & $27 \cdot 5$ & 0.88 & $I \cdot 30$ & 1.29 & $0.4 \mathrm{I}$ \\
\hline
\end{tabular}

a non-specific 'stress' action since quite unpleasant symptoms accompanied the ingestion of these large amounts of sodium salicylate. That a specific drug effect is concerned, whether direct or through adrenal activation, is suggested by experiments in which patients received sodium salicylate in moderate doses whilst on a diet providing a fairly constant (but not completely controlled) daily intake of ascorbic acid. In these experiments blood was withdrawn for analysis before breakfast, $\mathrm{r} 2 \mathrm{~h}$ after the last dose of salicylate (or possible ingestion of ascorbic acid). The one used here as an illustration (Table 5) is interesting in that a single

Table 5. Effect of daily administration of $7 \mathrm{~g}$ sodium salicylate in divided doses on the ascorbic-acid concentration of the plasma

\begin{tabular}{|c|c|c|c|c|}
\hline \multicolumn{5}{|c|}{$(\mathrm{mg} / 100 \mathrm{ml}$. plasma $)$} \\
\hline Day & Salicylate & Ascorbic acid & $\begin{array}{l}\text { 'Total' ascorbic acid } \\
\text { (method of Roe \& Kuether, I943) }\end{array}$ & $\begin{array}{l}\text { Dehydroascorbic } \\
\text { acid }\end{array}$ \\
\hline I & - & 0.46 & 0.85 & 0.39 \\
\hline 2 & - & 0.40 & 0.60 & 0.20 \\
\hline $3^{*}$ & - & 0.40 & 0.85 & 0.45 \\
\hline 4 & I 2 & 0.50 & 0.50 & o \\
\hline 5 & - & 0.40 & 0.55 & 0.15 \\
\hline 6 & - & 0.34 & 0.50 & 0.16 \\
\hline $7^{*}$ & - & 0.40 & 0.50 & 0.10 \\
\hline $8^{*}$ & I 8 & 0.40 & 0.40 & 0 \\
\hline $9^{*}$ & - & 0.28 & 0.30 & 0.02 \\
\hline Io* & - & 0.28 & 0.29 & 0.01 \\
\hline I I ${ }^{*}$ & - & 0.28 & 0.29 & $0.0 \mathrm{I}$ \\
\hline $12^{*}$ & - & 0.18 & 0.20 & 0.02 \\
\hline
\end{tabular}

* The salicylate was given on the days marked by an asterisk. 
dose of sodium salicylate was given prematurely and produced the temporary disappearance of dehydroascorbic acid already mentioned. When, 4 days later, regular administration of sodium salicylate ( $7 \mathrm{~g}$ /day in five doses) began, the dehydroascorbic acid vanished; in this instance, though not always, the total ascorbic-acid concentration of the plasma slowly fell.

\section{Relationship between the concentrations of plasma dehydroascorbic acid and blood glutathione}

We have not yet accumulated sufficient data to determine whether or not there is a correlation between the concentration of dehydroascorbic acid in the plasma and that of glutathione or oxidized glutathione in the blood cells. However, in one or two experiments with cortisone and $\mathrm{ACTH}$ it has been found that, coincident with the disappearance of dehydroascorbic acid from the plasma, there was a disappearance of glutathione (by conversion to the disulphide form) from the whole blood. The close parallelism illustrated in Table 6 , however, was not a regular occurrence, and sometimes the oxidized glutathione increased throughout the time

Table 6. Effect of ACTH or cortisone on plasma ascorbic acid and blood glutathione . (mg/roo ml.)

Plasma Blood

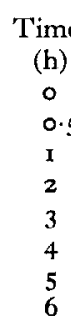

(a) $100 \mathrm{mg}$ ACTH given intramuscularly at time o

\begin{tabular}{|c|c|c|c|c|c|}
\hline $\begin{array}{l}\text { Cime } \\
\text { (h) }\end{array}$ & Ascorbic acid & $\begin{array}{c}\text { Dehydroascorbic } \\
\text { acid }\end{array}$ & Total & GSH & GSSG \\
\hline 0 & $I \cdot I 2$ & 0.08 & $I \cdot 20$ & $33 \cdot 4$ & $4 \cdot 6$ \\
\hline 0.5 & $1 \cdot 12$ & 0.08 & $I \cdot 20$ & $33 \cdot 7$ & $3 \cdot 1$ \\
\hline I & $1 \cdot 19$ & 0.01 & $1 \cdot 20$ & $33 \cdot 7$ & 3.7 \\
\hline 2 & $1 \cdot 30$ & 0 & $\mathrm{I} \cdot 30$ & $30 \cdot 4$ & $6 \cdot 4$ \\
\hline 3 & I.33 & 0.07 & $1 \cdot 40$ & $30 \cdot 4$ & $7 \cdot 6$ \\
\hline 4 & $I \cdot 33$ & 0.07 & $1 \cdot 40$ & 29.8 & $7 \cdot 6$ \\
\hline 5 & I.23 & 0.02 & I.25 & $3 r \cdot 3$ & $6 \cdot 7$ \\
\hline 6 & 1.05 & 0.15 & $I \cdot 20$ & $32 \cdot 5$ & $4 \cdot 3$ \\
\hline
\end{tabular}

(b) $350 \mathrm{mg}$ cortisone acetate given orally at time 0

$\begin{array}{lllll}0.45 & 0.15 & 0.60 & 51.5 & - \\ 0.45 & 0.14 & 0.59 & 49.1 & 2.4 \\ 0.52 & 0.09 & 0.61 & 50.9 & 0 \\ 0.60 & 0 & 0.60 & 51.5 & 0.6 \\ 0.44 & 0.15 & 0.59 & 52.1 & 0 \\ 0.43 & 0.17 & 0.60 & 50.3 & 0 \\ 0.42 & 0.17 & 0.59 & 51.5 & 2.5\end{array}$

of observation and particularly at a time when dehydroascorbic acid was returning to the plasma. These observations must be regarded as preliminary, to be extended with use of a method more specific than that of Woodward \& Fry (1932) hitherto employed. Nevertheless they do indicate some relationship between dehydroascorbic acid and cellular glutathione-as is to be expected-only partially detected, however, when only the blood cells are examined. Mr Bhattacharya, working in this laboratory, has detected a similar tendency to increase in the oxidized glutathione concentration of the blood in rats given injections of dehydroascorbic acid with the object of producing a diabetic state, the effect being manifest some 
days after the last injection. This tendency also must still be treated with some reserve since it may be merely residual from a direct oxidation of glutathione by the enormous amounts of dehydroascorbic acid previously in the circulation.

\section{Discussion}

It seems that dehydroascorbic acid exists in the plasma in equilibrium with ascorbic acid, that the relative amounts of the two substances can be altered by certain agents, ACTH, cortisone and salicylate. These three all reduce the dehydroascorbic acid. The effect appears to be cellular and to be associated with changes in the soluble sulphydryl compounds.

One of the fundamentally important effects of ACTH has been considered to be the reduction it causes in the amount of ascorbic acid in the adrenal glands; the results reported here suggest that this is only a part of the effect, another part of which is an alteration of the relative amounts of ascorbic acid and dehydroascorbic acid in the periphery under the influence of adrenocortical hormones.

Whatever the ultimate explanation may prove to be, the demonstration of dehydroascorbic acid in the plasma indicates a metabolic importance of the vitamin which was by no means self-evident when it was believed to exist solely in the reduced form.

\section{REFERENCES}

Loxton, G. E. \& LeVay, D. L. (1953). Nature, Lond., I71, 524.

Mapson, L. W. \& Ingram, M. (I95I). Biochem. F. 48, $55 \mathrm{I}$.

Roe, J. H. \& Kuether, C. A. (1943). F. biol. Chem. 147, 399.

Stewart, C. P., Horn, D. B. \& Robson, J. S. (1952). Biochem. F. 51, xx.

Stewart, C. P., Horn, D. B. \& Robson, J. S. (1953). Biochem. F. 53, 254.

Woodward, G. E. \& Fry, E. G. (1932). F, biol. Chem. 97, 455. 